\title{
RECONSTRUCTION OF REGULATION OF AUTHORITY TO PROSECUTE TASK UNIT FOR PREVENTION AND ERADICATION OF FOREST DAMAGE IN LAW NUMBER 18 OF 2013
}

\author{
Tjahjono Eko, Doctoral Candidate \\ Sudarsono, Budiono Abdul Rachmad, Professors \\ Madjid Abdul, Associate Professor \\ Faculty of Law, University of Brawijaya, Malang, Indonesia \\ *E-mail: ekotjahjono008@gmail.com
}

\begin{abstract}
Various forms of forestry crimes, especially illegal logging crimes committed in the illegal use of timber forest products and other actions in the form of illegal use of forest areas, also contribute to forest degradation and deforestation in Indonesia. Efforts to preserve forest have been realized in Law Number 18 of 2013 concerning Prevention and Eradication of Forest Destruction, which has given authority to the government through the Ministry of Environment and Forestry and the Regional Government where forest areas are located, as well as to the Institute for the Prevention and Eradication of Forest Destruction in the Law Number 18 of 2013, to carry out investigation activities up to the investigation of criminal acts of forest destruction as stipulated in Article 56 paragraph 1 letter a of Law Number 18 of 2013. The task force carries out strategic forest destruction eradication from investigation to prosecution throughout the territory of the Republic of Indonesia. Indonesia is included in the customs area at the behest of the head of the institution and/or deputies in accordance with the provisions of Article 55 paragraph 5 . The authority to prosecute institutions and task forces is not in line. It contains legal implications with other laws, namely Law Number 16 of 2004 concerning the Attorney General's Office of the Republic of Indonesia and Law Number 17 of 2006 concerning Customs. Therefore, it is necessary to reconstruct the prosecution authority by the agency's task force for the Prevention and Eradication of Forest Destruction in Law Number 18 of 2013.
\end{abstract}

\section{KEY WORDS}

Reconstruction, authority, prosecution, The Task Force for the Prevention and Eradication of Forest Destruction.

One of the causes of the degradation of Indonesia's forest resources is the practice of illegal logging. Illegal logging includes violations of the law that result in over-exploitation of forest resources and deforestation and forest destruction. These violations can occur at any stage of timber production such as in logging, transportation of raw materials, processing and trade, even involving illegal ways to gain access to the forest, violating customs regulations, violating financial administration such as avoiding paying taxes and money laundering (DPR $\mathrm{RI}, 2008$ ). While deforestation occurs due to a change in forest land use to non-forest, forest fires can occur either intentionally, negligently, or occur naturally.

As a step towards the realization of efforts to overcome the problem of forest destruction, the presence of institutions for preventing and eradicating forest destruction as mandated in Law Number 18 of 2013, is highly anticipated for their presence to answer these issues and to stop acts of forest destruction which is a must as stipulated in Article 111 of Law Number 18 of 2013. The mandate of Law Number 18 of 2013 for the Prevention and Eradication of Forest Destruction $(\mathrm{P} 3 \mathrm{H})$ is that the Institute for the Prevention and Eradication of Forest Destruction must have been established within two years of Law Number 18 of 2013 for the Prevention and Eradication of Forest Destruction (P3H) was promulgated on August 6, 2013, but until now the presence of an agency for preventing and eradicating forest destruction has not been responded to by the Government by issuing a Presidential Regulation or the President has not issued a Presidential Regulation regarding 
the existence of the Institute for Prevention and Control of Forest Destruction, Eradication of Forest Destruction. This means that the rules are contained in the provisions, namely Law Number 18 of 2013, but in the implementation of the Institute for the Prevention and Eradication of Forest Destruction, there is no organizational structure and working procedure in the presidential regulation. The Act can delegate further regulatory authority directly to Government Regulations, Presidential Regulations, Ministerial Regulations, or Provincial Regulations as needed for the law to be implemented. If the law determines so, the law's implementing regulations are the same as government regulations that are formal regulations that have a hierarchical position directly under the law (Asshiddiqie, 2018).

With the regulation of the Institute for the Prevention and Eradication of forest destruction to avoid further forest destruction, it will be possible to determine whether the implementation of the duties of the institution given in Law Number 18 of 2013 can be carried out and implemented in the context of establishing a task force for eradicating forest destruction as implementing elements of the LP3H who carry out the eradication of forest destruction from the investigation until the prosecution in Article 55 paragraph 5, the task arrangements of the institution and the task force of the agency are unclear, unclear, or there is the overlapping authority with other institutions or with other agencies, the duties of the institution in the Law Number 18 of 2013 so that the function of LP3H is difficult or cannot be implemented. The regulation of the tasks and authorities of the $\mathrm{P} 3 \mathrm{H}$ task force in terms of prosecution in Law Number 18 of 2013, there has been an overlap of authority (conflict of authority) with prosecution by the Public Prosecutor contained in Law Number 8 of 1981 concerning the Criminal Procedure Code (KUHAP) and Law Number 16 of 2014 concerning the Prosecutor's Office of the Republic of Indonesia, and Law Number 17 of 2006 concerning customs relating to areas or territories that are specifically designated for Customs and Excise institutions so that a restructuring of the arrangements is needed so that Law Number 18 of 2013 can be implemented in the future which will come. For a law to be formed properly, rational and systematic processing is not carried out just like that, but by taking into account that the law must be under the nation's needs. The last one by Von Jhering is labeled with the term national egoism (Huijbers, 2017).

In Law Number 18 of 2013 on Prevention and Eradication of Forest Destruction (P3H), it was found that the authority of the institution for the Prevention and eradication of forest destruction was found in establishing a task force as an implementing element to carry out strategic forest destruction eradication from investigation to prosecution, while the $\mathrm{P} 3 \mathrm{H}$ Institution in Law Number 18 of 2013 has the task of conducting investigations and investigations into criminal acts of forest destruction, so that the task authorities of the $\mathrm{P} 3 \mathrm{H}$ institution and the task force of the $\mathrm{P} 3 \mathrm{H}$ institution are not in line, meaning that the task of the institution and the task of the LP3H task force exceed the duties of the $\mathrm{P} 3 \mathrm{H}$ institution, besides that there has not been found a ratio legis from the regulation of the implementation of the task force in carrying out the eradication of forest destruction which is strategic from investigation to prosecution. Therefore, according to Moh Mahfud MD, there is no exaggeration. There is an impression that the formation of laws is not well prepared so that many laws do not meet the principles of law formation or are not worthy as laws. As a result, many laws cause problems because they cannot be implemented or overlap. The Constitutional Court has even canceled many through a judicial review (Mahfud, 2009).

The above conditions will lead to overlapping authority for prosecuting forest destruction cases with other institutions and the duties and authorities of prosecution by the task force making it ineffective and the function of law enforcement by forest destruction prevention and eradication institutions in eradicating forest destruction cannot be implemented, because there is no the basis of a clear regulation regarding the regulation of the Forest Destruction Prevention and Eradication Agency in forming a task force related to prosecution actions, this authority is contrary to the authority of the $\mathrm{P} 3 \mathrm{H}$ Institution, so that there will be deviations from the principles that can be implemented, namely the principle of usability and usability, the principle of clarity formulation of legal certainty, as well as deviations from the principle of dominus litis, namely the prosecutor as the controller of the case and the principle of the sole public prosecutor with the Prosecutor's Office of the 
Republic of Indonesia in Law Number 16 of 2004 which in practice for the separation of the functions of investigators and public prosecutors or better known as functional differentiation.

Re-arrangement of the legal ratio of the Institute for the Prevention and Eradication of Forest Destruction in Law Number 18 of 2013 in the formation of a task force that is given the task and authority to handle forest destruction from the investigation to the prosecution is necessary so that the functions of the P3H Institution of Law Number 18 of 2013 can be enforced and avoid the overlapping powers of prosecution by the Public Prosecutor as stipulated in the Criminal Procedure Code and Law Number 16 of 2004 and Law Number 17 of 2006 concerning Customs. In Law Number 16 of 2004 concerning the Prosecutor's Office, the Republic of Indonesia is the only institution authorized to carry out prosecutions carried out by the Public Prosecutor. The public prosecutor himself is a Prosecutor. On the other hand, the arrangement of the duties of the public prosecutor has been explained in Law Number 18 of 2013. Basically, the law has regulated the existence of a task force and public prosecutor. In Law Number 8 of 1981 concerning the Criminal Procedure Code as the applicable procedural law as stated in article 8 paragraph (3) of Law Number 18 of 2013, it has also regulated what is the authority of the public prosecutor, while the task force does not have a regulation in the Criminal Procedure Code that can become a public prosecutor to prosecute. The legal problem in this research is regarding the provisions of Article 55 paragraph 5 of Law Number 18 of 2013, which is considered a conflict of norms based on the provisions of the Criminal Procedure Code and Law Number 16 of 2004 and Law Number 17 of 2006 concerning amendments to Law Number 10 of 1995 concerning Customs.

\section{METHODS OF RESEARCH}

The approach method in this research is juridical empirical to find out how the relationship between law and society and the factors influencing the implementation of law in society, as primary data. The second data is obtained indirectly through library research. This research specification describes an analysis to describe the applicable law related to law and positive law about the main research problem, based on primary and secondary data, identification, classification, and validation. Qualitative data analysis was carried out, and the results were displayed in the research report.

\section{RESULTS AND DISCUSSION}

Reconstruction of Prosecution Authority by the $\mathrm{P} 3 \mathrm{H}$ Institution Task Force in Law Number 18 of 2013. According to Dominikus Rato, the first thing to emphasize is that law is a tool, not an end. Because as a tool, the law is not always maintained, meaning that the law is always sought for its formulation according to the community's needs (Rato, 2017). Deconstruction of urgent law is also carried out based on the consideration that the power structure in society, including the government, is a hierarchy building that is very rigid and not easily responsive to public demands, besides that it is an action to make comprehensive, fundamental, and rapid and drastic changes, as which is discoursed in the type of progressive law (Rahardjo, 2007).

The reconstruction of the prosecution authority arrangement by the task force resulting from the formation of the $\mathrm{P} 3 \mathrm{H}$ institution as an ideal $\mathrm{P} 3 \mathrm{H}$ implementing element is the reinterpretation of the provisions of Article 55 paragraph 5 of Law Number 18 of 2013 in terms of the nature of the task force carrying out the eradication of forest destruction that is organized from investigation to investigation throughout the territory. The Unitary State of the Republic of Indonesia. The construction of article 55 paragraph 5 from an ontological point of view is a task force carrying out the eradication of forest destruction that is strategic from investigation to prosecution throughout the territory of the Unitary State of the Republic of Indonesia, including customs areas at the behest of the Head of Institution and/or Deputy.

The goals of the ontology of science are concerned (Poesoko, 2018):

- Problems regarding the existence of science itself;

- The essence that exists, namely something scientific as the deepest essence; 
- The number of essences whose implications for the theory of truth, coherence, pragmatism, theology, positivism;

- The structure of nature related to what science is built for;

- Changeable or permanent or absolute or relative;

- The nature of causality;

- God.

From this ontological target, the essence of Article 55 paragraph 5 of Law Number 18 of 2013 is aimed at eradicating forest destruction, which actions are stated in the form of prosecution. What is the reality of the prosecution like, and what is the existence of the prosecution like.

The discussion on the prosecution authority by the LP3H task force in eradicating forest destruction means seeking the essence of prosecution authority in handling cases. Based on this view and the theory of law formation as in the view of A Hamid S Attamimi, it is explained that the principles of forming good legislation are legal principles that provide guidance and guidance for the pouring of the contents of the regulations into the appropriate form and arrangement, appropriate in the use of the method, and following a predetermined formation process and procedure (Attamimi, 1993). In addition, Law Number 30 of 2014 concerning Government Administration, in its explanation, states that administering the state government of the Republic of Indonesia must be based on the principle of people's sovereignty and the principle of the rule of law. Based on these principles, all forms of Government administrative decisions and/or actions must be based on the sovereignty of the people and the law, which reflects Pancasila as the state ideology. Thus, it is not based on the power inherent in the position of the government administrator itself, and the use of state power over the citizens is not without conditions. Citizens cannot be treated arbitrarily as objects. Decisions and/or Actions against Citizens must be under the provisions of laws and regulations and general principles of good governance. Systems and procedures for the implementation of government and development tasks must be regulated by law. Therefore, the provisions of Article 55 paragraph 5 of Law Number 18 of 2013 need to be reorganized so that harmonization occurs, there is no overlapping of authorities, and there is no mixing of powers held by the $\mathrm{P} 3 \mathrm{H}$ Institution, especially in the case of the prosecution.

In criminal procedural law, the prosecutor's office is an institution with the main task and function of the prosecution authority, which always holds the dominus litis principle (case controller). The single prosecution system (single public prosecutor) becomes the monopoly of the prosecutor and/or public prosecutor in prosecuting a case, a monopoly for the prosecution of cases. Criminal jurisdiction is regulated in Law Number 16 of 2004 concerning the Attorney General's Office of the Republic of Indonesia. The process of establishing the Criminal Procedure Code as procedural law in Law Number 18 of 2013 is an affirmation of the dominus litis principle or case-control and limitation of prosecution authority within protecting human rights. Therefore, humans are always bound by formal rules, rules that respect the existence of human rights.

For this reason, humans become legal subjects, a position that places humans as holders of rights, obligations, and responsibilities. Therefore humans are protected by law. The legal guidelines for handling forest destruction cases in Law Number 18 of 2013 in the Criminal Procedure Code are intended to provide protection for human rights from the time of the investigation, being designated as a suspect and being prosecuted as a defendant in the context of dealing with the arbitrariness of the state represented by law enforcement officers from the beginning. investigation to the trial process of cases, and legal remedies, both ordinary legal remedies and extraordinary legal remedies.

The provisions in Article 55 paragraph 5 of Law Number 18 of 2013 at the implementation level raise problems, besides the organizational structure and work procedures of the $\mathrm{P} 3 \mathrm{H}$ Institution, have not been regulated in the Presidential Regulation or related to the prosecution authority between the task force of the $\mathrm{P} 3 \mathrm{H}$ institution and the prosecutor's agency. The problems that arise in the provisions of article 55, paragraph 5, cannot be solved by the Criminal Procedure Code. In its development, the goal of achieving justice, certainty, and benefit from the formation of Law Number 18 of 2013 has not been 
achieved. Gustav Radbruch, as quoted by Dominikus Rato, divides three fields of study, which are the objectives of legal philosophy to seek, find and analyze them, namely the aspect of justice, namely concerning harmony, balance, and harmony between the rights and obligations of legal subjects; aspects of the objective of justice or finality, namely determining the content of the law so that it is in line with the objectives to be achieved with the law as an instrumental; and aspects of legal certainty or legality, namely ensuring that the law can provide and establish rights to something from a person as a legal subject (Rato, 2017).

Such problems arise because the formation of laws or legal provisions is not under what should be ideal, legitimate, as expected under the criteria made at its formation. The function of law as a norm/regulation becomes overlapping, and a conflict of norms occurs. Legal products do not function under the principles of justice and legal certainty. Elucidation of Article 2 letter a of Law Number 18 of 2013 states that what is meant by justice and legal certainty is the prevention and eradication of forest destruction, which is carried out based on law/statutory provisions and law enforcement applies to all levels of society.

The imperfection of a legal product is a legal problem both axiologically and epistemologically. It is a weakness of written legal products that require a reconstruction of the meaning of a legal provision that is a conflict of norms, in this case, the provisions of Article 55 paragraph 5 of Law Number 18 of 2013. The reconstruction of Article 55 paragraph 5 of Law number 18 of 2013 becomes very relevant to deconstruct the prosecution authority by the task force. The understanding of Article 55 paragraph 5 of Law Number 18 of 2013 brings legal consequences that the prosecution authority by the task force in eradicating forest destruction that has been granted by Law Number 18 of 2013 can no longer be maintained. There is no legal certainty in its application and causes injustice if applied in the handling of cases of forest destruction between the prosecution of the $\mathrm{P} 3 \mathrm{H}$ task force and the prosecution agency of the Prosecutor's Office in Law Number 16 of 2004 using the same criminal procedure law guidelines, namely Law Number 8 of 1981 concerning the Criminal Procedure Code. This condition is one of the factors of difficulty in prosecuting violations of the law, which is the main cause of the weakness of the judicial, executive power and the escape of forest destruction crimes.

The most important part in the formation of a law product, especially the product of Law Number 18 of 2013, must pay attention to the principles and principles of the formation of good legislation as stipulated in the norms of Law Number 15 of 2019 concerning amendments to Law Number 12 of 2011 concerning the formation of laws and regulations.

Gustav Radbruch's view on legal ideals in the form of a guide between certainty, benefit and justice is still considered a relevant view when it is associated with the principles contained in Law No. 18 of 2013 concerning legal objectives to describe certainty, benefit and justice, Article 2 of Law No. 18 In 2013 the eradication of forest destruction is based on one of the principles in letter a. namely justice and legal certainty.

Understanding the provisions that regulate the ideal authority for prosecuting forest destruction to achieve justice and legal certainty is based on the nature of the prosecution's authority by the public prosecutor. The reconstruction that has been carried out is a reconstruction that provides and offers new alternatives in providing a new meaning in the provisions of Article 55 paragraph 5 of Law Number 18 of 2013. The reinterpretation as described previously, is based on a constructive method through a philosophical approach and an analytical approach to law based on theory economics of law and the formation of law as well as the concept of prosecution and public prosecutor to improve the provisions of article 55 paragraph 5 of Law Number 18 of 2013 where the norm is that there is a conflict which should have a complete norm and not cause conflict with other laws, namely Law Number 8 of 1981 concerning KUHAP, Law Number 16 of 2004 concerning the Attorney General's Office of the Republic of Indonesia and Law Number 17 of 2006 concerning Amendments to Law Number 10 of 1995 concerning Customs.

The new meaning of the task force carrying out the eradication of forest destruction that is strategic from investigation to prosecution throughout the territory of the Unitary State of the Republic of Indonesia, including the customs area at the behest of the head of the institution and/or deputies is contained in the provisions of Article 55 paragraph 5 of Law 
Number 18 of 2013 with the deconstruction that Some are derived from the Criminal Procedure Code, Law Number 16 of 2004 and Law Number 17 of 2006 concerning Customs as well as judges' decisions and the theory of law formation so that philosophically, theoretically and juridically it can reconstruct the meaning of the ideal prosecution authority to perfect the provisions of Article 55 paragraph 5 of Law Number 18 of 2013.

Reconstruction of the ideal prosecution authority in handling forest destruction cases in Law Number 18 of 2013. The reconstruction of Article 55, paragraph 5 of Law Number 18 of 2013 concerning the reconstruction of the task force's authority arrangement in the prosecution authority is ideally reinterpreting article 55 paragraph 5 , which is the meaning of the prosecution authority by the $\mathrm{P} 3 \mathrm{H}$ task force under the law. The construction of article 55, paragraph 5 of Law Number 18 of 2013 concerning P3H from an ontological perspective is about the basis of the prosecution authority by public prosecutors based on the Criminal Procedure Code and Law Number 16 of 2004.

The search for the basic prosecution authority in the Criminal Procedure Code and in Law Number 16 of 2004 leads to an ontological study, namely the nature of the authority to be studied. Ontology deals with what is the nature of science, what is the essence of truth, and the reality of what and how "is" (being, sein, het zijn), because it deals with "metaphysics". Literally, "metaphysics" means outside of "physics" because meta means "outside". Operationally, "metaphysics" can be defined as part of human knowledge that deals with the question of the deepest nature of "being" (Atmadja et al., 2014). Still, according to I Dewa Gede Atmadja et al., the object of science as a phenomenon to be studied or studied and researched is usually divided into formal objects and material objects. The content object in English is called subject matter, which can be the same or overlap (convergence) between one branch of science and another. While the formal object, which in English is called the "focus of the interest" (center of attention), is what distinguishes the field or branch of science from one another, therefore each branch of science has a different formal object (Atmadja et al., 2014).

Based on the above view, the essence of the prosecution authority of the $\mathrm{P} 3 \mathrm{H}$ agency task force which carries out the authority of the Public Prosecutor is the same as discussing the same subject matter as prosecution by the Public Prosecutor of the Criminal Procedure Code and in Law Number 16 of 2004 can be reviewed based on an ontological study. The focus of attention is the task force of the $\mathrm{P} 3 \mathrm{H}$ institution resulting from establishing the $\mathrm{P} 3 \mathrm{H}$ institution is given the authority to prosecute the reality of the prosecution and its existence. In contrast, within the authority of the $\mathrm{P} 3 \mathrm{H}$ institution, there is no subject matter related to prosecution, so that the prosecution authority needs to be studied.

The discussion regarding the authority to prosecute in cases of forest destruction in the Criminal Procedure Code and Law Number 16 of 2004 and Law Number 18 of 2013 is always related to the authority of the study of government administration according to Law Number 30 of 2004 concerning government administration because prosecution activities are related to administrative activities to carry out government activities.

The provisions of Article 55 paragraph 5 of Law Number 18 of 2013 in its application raise problems. Problems arise when the Criminal Procedure Code and Law Number 16 of 2004 regulate the same problem regarding prosecution. In such conditions, there is no solution to the problem of prosecution authority. This problem arose because the legislators ignored the provisions regarding the formation of legislation Number 15 of 2019 concerning amendments to Law Number 12 of 2011 concerning the Establishment of Legislation. The regulatory ratio legis is not correct. It has not been appropriately formulated in the provisions of the articles. And the legislators are wrong in using the legal concept of the meaning or phrase of the word prosecution. The legislators have not yet thought about or have not been able to predict what actions will need harmony or harmony in the future. In the study of academic manuscripts, there is no anticipation of the emergence of such a conflict of prosecution authority.

The problem of the imperfection of a legal product is caused by the factors mentioned above. Therefore, it is necessary to reconstruct the understanding of a legal provision that is strict and rigid in terms of the provisions of Article 55 paragraph 5 of Law Number 18 of 2013 
concerning $\mathrm{P} 3 \mathrm{H}$. The application of strict criminal sanctions in the implementation of Law Number 18 of 2013 aims to understand the sense of justice in the community for the enactment of criminal provisions in it, both as perpetrators of individual crimes and as legal entities or corporations. The objectives of criminal law are as follows:

1. To scare people from committing crimes, either by scaring people away (general preventive) or by scaring certain people who have committed crimes so that they will not commit crimes again (special prevention);

2. To educate or improve people who have indicated they like to commit crimes so that they become people of good character so that they are beneficial to society (Prodjodikoro, 2003).

Reconstruction of the provisions of Article 55 paragraph 5 of Law Number 18 of 2013 concerning $\mathrm{P} 3 \mathrm{H}$ must be interpreted in order to understand the prosecution authority by the public prosecutor by the Prosecutor's Office as the holder or monopolist of demands in criminal cases or single prosecution systems.

In the perspective of the theory of authority, the authority becomes valid if it is given to legitimate authority. Thus the reconstruction of the prosecution authority by the public prosecutor in the case of forest destruction is rebuilt based on legal authority based on the provisions of the law, under the nature and purpose of the prosecution, namely for the validity of delegating the case to the court with a request that immediately adjudicates the case accompanied by an indictment.

The reinterpretation of Article 55 paragraph 5 of Law Number 18 of 2013 is based on a method built on the basic foundations of ontology, by conducting technical analysis studies by conducting studies based on the stages of construction and reconstruction. The foundation of the following science is Epistemology etymologically, "epistemology" is defined as "theory of knowledge" comes from the Greek language, namely "Episteme" = knowledge and "Logis" = theory. The Encyclopedia of Philosophy means that "epistemology or the theory of knowledge is that branch of Philosophy which is concerned with the nature and scope of knowledge, its presuppositions and basis and in the general reliability of claims to knowledge general claims to the knowledge possessed (Atmadja et al., 2014).

Thus, it means a theory of knowledge. Epistemology examines what science is, where the source of knowledge is, and how the process occurs. Epistemology is the way how to get understanding, the sources of knowledge, the scope of knowledge. People with different backgrounds, needs, and interests must be faced with questions like where do I come from? How does the natural creation process occur? What is human nature? The benchmark of good and evil for humans? What is the factor of the perfection of the human soul? Where are the right and just government? Why is justice good? At what degree does water boil? Does the earth revolve around the sun or vice versa? And other questions. The demands of human nature and their deep curiosity must find answers and solutions to these problems and the things they will face. Humans want to reach reality and try to know something they don't know (Suaedi, 2016). The study of epistemology will rise whether the prosecution and the source or basis of the prosecution are obtained from the activities of experience and knowledge.

The prosecution authority in the Criminal Procedure Code and Law No. 16 of 2004 and the prosecution authority in Law No. 18 of 2013 will certainly experience conflicts regarding the application of the law regarding the limits or parameters of prosecution authority. The conflict arises because, on the one hand, the authority to prosecute a case lies with the Public Prosecutor in the Prosecutor's Office based on Law Number 16 of 2004, while on the other hand, the prosecution authority in Law Number 18 of 2013 is given to the task force as an implementing elements of the $\mathrm{P} 3 \mathrm{H}$ Institution.

From this conflict, the reconstruction of the most appropriate or ideal method is to carry out a total synthesis of the provisions of Article 55 paragraph 5 of Law Number 18 of 2013 to provide a way out to find the validity of the prosecution. The new editorial offered regarding prosecution in the case of forest destruction will be included in the rule of law in article 55, paragraph 5 and included in addition to the explanation of article 55 paragraph 5 of Law Number 18 of 2013. 
The new editorial provisions in the legal rules contained in article 55, paragraph 5 are:

1. The task force carries out the eradication of forest destruction that is organized systematically and extraordinarily from the investigation to the investigation throughout the territory of the Unitary State of the Republic of Indonesia, on the orders of the head of the institution and/or the deputy;

2. The additional provisions in the explanation are that efforts to deal with forest destruction have been carried out for a long time but have not been carried out effectively and have not shown optimal results. This is partly because the existing laws and regulations do not explicitly regulate criminal acts of forest destruction that are carried out systematically and extraordinarily.

\section{CONCLUSION}

The provisions of Article 55 paragraph 5 of Law Number 18 of 2013 states that the task force carrying out the eradication of forest destruction that is strategic from the investigation to the prosecution in the entire territory of the Unitary State of the Republic of Indonesia, including the customs area at the behest of the head of the institution and/or deputies, needs to be reconstructed, re-arranged. The provisions regarding eradicating forest destruction from investigation to the prosecution until the Customs area conflicted with norms with Law Number 16 of 2004, which has the authority to prosecute by public prosecutors/Prosecutors and Law Number 17 of 2006. Customs areas become the domain of the Customs institution. This creates a conflict of norms and legal uncertainty. Although the regulation regarding LP3H has not been determined in a Presidential Regulation, it is necessary to reconstruct and re-arrange Article 55 paragraph 5 . The provisions of this article create conflicting norms regarding the authority to persecute and multiple interpretations regarding the authority to persecute forest destruction. This is also based on the fact that the $\mathrm{P} 3 \mathrm{H}$ Institution does not have the authority to prosecute in the provisions of Law Number 18 of 2013. In article 56, paragraph 1 letter a LP3H has the task of conducting investigations.

In the absence of a prosecution authority function owned by the institution, and the provisions in Article 55 paragraph 5 regarding the prosecution authority possessed by the task force, there will be a mixing of the authority and authority of the task force in prosecution activities that have exceeded the authority of LP3H, and this not justified according to the provisions of Article 17 of Law Number 30 of 2014 concerning government administration, namely:

1. Government agencies and/or officials are prohibited from abusing their authority;

2. The prohibition of abuse of authority as referred to in paragraph (1) includes: prohibition of exceeding the authority; prohibition of mixing authority; and/or prohibition of acting arbitrarily.

Violation of these provisions will result in invalid decisions as stipulated in Article 70 paragraphs 1, 2, and 3 of Law Number 30 of 2014. The new editors mentioned above are the results of the reconstruction of Article 55 paragraph 5 of Law Number 18 of 2013, which are included and proposed in the national legislation program to make changes to the sound provisions regarding prosecution's authority by the task force.

\section{REFERENCES}

1. Asshiddiqie, J. (2018). Perkembangan Baru Tentang Konstitusi and Konstitusionalisme Dalam Teori and Praktek. Yogyakarta: Genta Publising.

2. Atmadja, I et al. (2014). Filsafat Ilmu. Malang: Madani.

3. Attamimi, A. (1993). Hukum Tentang Peraturan Perundang Undangan and Peraturan Kebijakan Hukum Tata Pengaturan. Jakarta: Fakultas Hukum UI.

4. DPR RI. (2008). Naskah Akademik RUU Tentang Pencegahan and Pemberantasan Pembalakan Liar. Jakarta: DPR RI.

5. Huijbers, T. (2017). Filsafat hukum. Yogyakarta: Kanisius. 
6. Mahfud, M. (2009). Konstitusi and Hukum dalam Kontroversi Isu. Jakarta: RajawaliGrafindo Persada.

7. Poesoko, H. (2018). IImu Hukum Dalam Perspektif Filsafat IImu. Yogyakarta: LaksBang PRESSindo.

8. Prodjodikoro, W. (2003). Asas-Asas Hukum Pidana di Indonesia. Jakarta: Refika Aditama.

9. Rahardjo, S. (2007). Membedah hukum progesif. Jakarta: Kompas Gramedia.

10. Rato, D. (2017). Pengantar filsafat Hukum. Yogyakarta: LaksBang Pressindo.

11. Suaedi. (2016). Pengantar Filsafat IImu. Bogor: IPB Press. 